\title{
Detection of $\beta$-lactamase, blaZ and mecA in penicillin-resistant Staphylococcus aureus isolated from bovine mastitis in Garanhuns, Brazil
}

\section{Detecção de $\beta$-lactamase, blaZ e mecA em amostras de Staphylococcus aureus resistentes à penicilina isoladas de mastite bovina em Garanhuns, Brasil}

\author{
Amanda Pereira Lucas ${ }^{(10 ;}$; Andriele Renata Barbosa de Farias ${ }^{a}$ (D); Elizabete Cristina da Silva ${ }^{b}$ (D); \\ Kleber Régis Santoroa (i); Marcelo Mendonça ${ }^{a}$ (i); Elizabete Rodrigues da Silva ${ }^{a^{*}}$ (1)
}

\begin{abstract}
There are few reports in the literature about genetic determinants of resistance to $\beta$-lactams in Staphylococcus aureus isolated from dairy cattle located in the municipality of Garanhuns, state of Pernambuco, Brazil. Thus, this study aimed to investigate the production of $\beta$-lactamase and the presence of the bla $\mathrm{Z}$ and mec $\mathrm{A}$ genes in penicillin-resistant $S$. aureus isolated from cases of subclinical bovine mastitis in the city of Garanhuns. Forty-six strains of penicillin-resistant $S$. aureus were evaluated using the nitrocefin disc test and duplex PCR. The results revealed that 45 strains $(97.8 \%)$ were positive for $\beta$-lactamase production and $44(95.7 \%)$ carried the blaZ gene. Among the latter, $43(97.7 \%)$ were $\beta$-lactamase producers and only one $(2.3 \%)$ was not. The $m e c A$ gene was not detected in any of the isolates investigated. The results suggest that enzymatic inactivation is the main $\beta$-lactam resistance mechanism expressed by $S$. aureus in the herds analyzed.
\end{abstract}

KEYWORDS: staphylococcal mastitis; antimicrobial resistance; $\beta$-lactam antibiotic.

\begin{abstract}
RESUMO: Existem poucos relatos na literatura sobre determinantes genéticos da resistência aos $\beta$-lactâmicos em Staphylococcus aureus isolados em rebanhos de bovinos leiteiros localizados no município de Garanhuns, estado de Pernambuco, Brasil. Dessa forma, este estudo teve como objetivo investigar a produção de $\beta$-lactamase e a presença dos genes blaZ e mecA em $S$. aureus resistentes à penicilina isolados de casos de mastite bovina subclínica na cidade de Garanhuns. Quarenta e seis amostras de $S$. aureus resistentes à penicilina foram avaliadas usando o teste do disco de nitrocefina e PCR duplex. Os resultados demonstraram que 45 amostras $(97,8 \%)$ foram positivas para a produção de $\beta$-lactamase e $44(95,7 \%)$ portavam o gene blaZ. Destes últimos, $43(97,7 \%)$ eram produtores de $\beta$-lactamase e apenas um $(2,3 \%)$ não produziu essa enzima. $\mathrm{O}$ gene mecA não foi detectado em nenhum dos isolados investigados. Os resultados sugerem que nos rebanhos avaliados a inativação enzimática é o principal mecanismo de resistência aos $\beta$-lactâmicos expresso por $S$. aureus.
\end{abstract}

PALAVRAS-CHAVE: mastite estafilocócica; resistência antimicrobiana; $\beta$-lactâmicos.

\section{INTRODUCTION}

Staphylococcus aureus (S. aureus) is one of the most important Gram-positive pathogens causing infectious diseases in several animal species. Diseases in humans range from mild infections located on the skin and soft tissues to severe diseases, such as endocarditis, pneumonia, septicemia, and toxic shock syndrome (AGUAYO-REYES et al., 2018; GARCÍA-ALVAREZ et al., 2011; OTTO, 2014).
In worldwide, mastitis by that bacteria is one of the most important diseases, particularly in dairy herds (ABEBE et al., 2016; FELIPE et al., 2017; FREITAS et al., 2018; LAVOR et al., 2019).

From an economic point of view, mastitis is the most important illness in dairy herds because losses due to costs related to treatment, prevention, and technical assistance as well as discarded milk and a reduction in milk production

\footnotetext{
(a)Laboratório de Microbiologia Animal - Universidade Federal do Agreste de Pernambuco/UFAPE, Av. Bom Pastor, S/N, Boa Vista, CEP.: 55292-272, Garanhuns, Pernambuco, Brazil. (b)Departamento de Zootecnia - Universidade Federal Rural de Pernambuco, campus Recife, Rua Dom Manuel de Medeiros, S/N, Dois Irmãos, CEP.: 52171-900, Recife-PE. *Corresponding author: beteers@hotmail.com 
(HOGEVEEN; VAN DER VOORT, 2017). Mastitis is also of considerable public health importance, as causal agents and antimicrobial residues can be transmitted through milk and other dairy products to consumers (ARAÚJO et al., 2014; BORELLI et al., 2006; MIRANDA; ARANGO, 2016).

The frequency of $S$. aureus mastitis in dairy cattle varies depending on the breed, management system and type of milking (ABEBE et al., 2016). In Brazilian herds, this pathogen is isolated at high frequencies (CUNHA et al., 2015; FREITAS et al., 2018; GIRARDINI et al., 2016; MESQUITA et al., 2019; SILVA et al., 2012) as well as in other countries (ABEBE et al., 2016; FELIPE et al., 2017; LIU et al., 2017).

Mastitis caused by $S$. aureus is usually treated with intramammary antimicrobials agents and $\beta$-lactams are the most extensively used class (Krewer et al., 2014). However, such use may contribute to the selection and dissemination of multidrug-resistant strains at a farm level (KLIMIENE et al., 2016).

In the genus Staphylococcus, resistance to $\beta$-lactam antimicrobials is encoded by chromosomes or plasmids genes. Two different resistance mechanisms are known: the production of $\beta$-lactamase and modification of the drug target. $\beta$-lactamase comprises a group of enzymes that hydrolyze the $\beta$-lactam ring of the $\beta$-lactams antimicrobials. The synthesis of different types of enzyme is encoded by the blaZ gene harbored in bacterial plasmids or chromosomes (FERREIRA et al., 2017; OLSEN; CHRISTESEN; AARESTRUP, 2006).

The modification of the drug target is represented by an altered penicillin-binding protein (PBP2a or PBP2') that has a poor affinity to the $\beta$-lactams antimicrobials (HARRISON et al., 2014; KLIMIENE et al., 2016). The mecA gene and its homologues (mecB and $m e c \mathrm{C}$ ) are the responsible for the genetic code of the altered PBP and are acquired as part of a mobile genetic element known as staphylococcal cassette chromosome mec (SCCmec) located on the bacterial chromosome. The mec genes, together with inducer/repressor and recombinase genes, comprise the well-studied mec complex (AGUAYO-REYES et al., 2018; ARÍZA-MIGUEL et al., 2014; LIU et al., 2016; LONCARIC et al., 2019; MacFADYEN et al., 2019).

In recent years, studies have reported a high incidence of resistance to penicillin and other $\beta$-lactams in $S$. aureus isolated from dairy cattle (FREITAS et al., 2018; GIRARDINI et al., 2016; KREWER et al., 2014; LIU et al., 2017; SILVA et al., 2012; YANG et al., 2015). However, investigations of the genetic determinants of $\beta$-lactam resistance are scarce, particularly in terms of $S$. aureus isolated from dairy cattle in the municipality of Garanhuns, state of Pernambuco, Brazil.

Thus, this study aimed to detect $\beta$-lactamase production and the presence of blaZ and mecA genes in penicillinresistant $S$. aureus isolated from subclinical bovine mastitis in Garanhuns, PE, Brazil.

\section{MATERIALS AND METHODS}

Forty-six strains of $S$. aureus were isolated from the milk of cows with subclinical mastitis in commercial dairy herds located in the municipality of Garanhuns in the state of Pernambuco, Brazil. The collection of milk samples and bacteriological analyses were carried out in a previous study (Silva et al., 2012). The strains were kept frozen at $-70^{\circ} \mathrm{C}$ in a skim milk based medium enriched with $15 \%$ glycerol. To carry out the studies, the samples were reactivated on $5 \%$ sheep blood agar.

The penicillin-resistance profile was previously investigated (Silva et al., 2012). All 46 S. aureus strains exhibited an inhibition zone of $\leq 28 \mathrm{~mm}$ to penicillin (penicillin G $10 \mathrm{U}$, CECON, São Paulo, Brazil) in the agar diffusion test, according to the guidelines of the Clinical and Laboratory Standards Institute (CLSI, 2008).

The production of the $\beta$-lactamase was detected by nitrocefin disc test (CEFINASE DISCS ${ }^{\circledR}$, Becton, Dickinson and Company, Franklin Lakes, NJ, USA), according to manufacturer's recommendations. Briefly, discs were moistened with $30 \mu \mathrm{L}$ of sterile purified water and bacterial samples were spread over the surface. A positive reaction in the first five minutes was defined by a red color, whereas a lack of color change denoted a negative reaction. In this case samples were left at room temperature for $1 \mathrm{~h}$, when the final reading was performed. Staphylococcus aureus ATCC 29213 was the positive control.

The genomic staphylococcal DNA extraction was performed using the heating method described by Hassanzadeh et al. (2016), with few modifications. Briefly, the isolates were grown in tryptic soy broth (TSB) and left approximately $16 \mathrm{~h}$ at $37^{\circ} \mathrm{C}$. After, $1 \mathrm{~mL}$ of each cultured bacteria was retrieved by centrifugation at $14000 \mathrm{rpm}$ for 5 minutes. The obtained pellet was subjected to wash using $500 \mu \mathrm{L}$ of lysis buffer $(20 \mathrm{mM}$ EDTA $+20 \mathrm{mM}$ Tris $\mathrm{pH} 7.5+75$ $\mathrm{mM} \mathrm{NaCl}$ ) and again centrifuged. The resulting pellet was resuspended in $300 \mu \mathrm{L}$ of the same lysis buffer, boiled and cooled twice (two minutes each step). Next, $30 \mu \mathrm{L}$ of lysozyme $(1 \mathrm{mg} / \mathrm{mL})$ were placed into the tube and incubated at $37^{\circ} \mathrm{C}$ for $1 \mathrm{~h}$, followed by the addition of $33 \mu \mathrm{L}$ of $10 \%$ SDS, incubation at $55^{\circ} \mathrm{C}$ for $1 \mathrm{~h}$ and cooling on ice for 10 minutes. In the next step, $120 \mu \mathrm{L}$ of $3 \mathrm{M}$ sodium acetate were added and the samples were cooled again. Last, the pellet was sequentially washed with chloroform, isopropanol and ethanol, DNA eluted in $30 \mu \mathrm{L}$ of sterile TE $\mathrm{pH} 7.5$, quantified in NanoDrop spectrophotometer (GE Healthcare Life Science) and kept frozen at $-20^{\circ} \mathrm{C}$.

The quality of the genomic DNA extracted was assessed by conventional PCR using the $16 \mathrm{~S}$ primer pair - F 5'GTA GGT GGC AAG CGT TAT CC 3'- and - R 5'CGC ACA TCA GCG TCA G 3' (MONDAY; BOAHACH, 1999). A specific segment of the genus Staphylococcus was amplified by preparing a reaction with a final volume of $30 \mu \mathrm{L}$ composed of $27 \mu \mathrm{L}$ of PCR Supermix (Invitrogen, Thermo 
Fisher Scientific, Waltham, MA, USA), $1 \mu \mathrm{L}(10 \mathrm{nM})$ of each primer and $1 \mu \mathrm{L}$ of template DNA (corresponding to 197 ng of genomic DNA). PCR amplification was carried out following steps of initial denaturation for 5 minutes at $94^{\circ} \mathrm{C}$, followed by 36 cycles of denaturation for 45 seconds at $94^{\circ} \mathrm{C}$, annealing for 30 seconds at $50.2^{\circ} \mathrm{C}$, extension for 30 seconds at $72^{\circ} \mathrm{C}$, and a final extension for 10 minutes at $72^{\circ} \mathrm{C}$. For duplex PCR, a reaction was prepared with the two primer pairs: mecAF - 5' GTA GAA ATG ACT GAA CGT CCG ATA A 3'/mecAR - 5' CCA ATT CCA CAT TGT TTC GGT CTA A 3' (FONTES et al., 2013) and blaZF - 5' AAG AGA TTT GCC TAT GCT TC 3'/blaZR - 5' GCT TGA CCA CTT TTA TCA GC 3' (SAWANT; GILLESPIE; OLIVER, 2009) with $0.25 \mu \mathrm{L}(25 \mathrm{pM})$ of each mecA primer, $0.4 \mu \mathrm{L}(40 \mathrm{pM})$ of each blaZ primer, $2 \mu \mathrm{L}$ of the multiplex PCR mix (Solis, Biodyne, Tartu, Estonia) and $0.5 \mu \mathrm{L}$ of template DNA (corresponding to $98.5 \mathrm{ng}$ of genomic DNA). The final volume was adjusted to $10 \mu \mathrm{L}$ with sterile ultrapure water. Amplification was performed with an initial activation for 12 minutes at $95^{\circ} \mathrm{C}$ and initial denaturation for 5 minutes at $94^{\circ} \mathrm{C}$, followed by 36 cycles as described for the $16 \mathrm{~S}$ primer reaction. Positive (DNA from the strain Staphylococcus capitis subsp. ureolyticus K22H/RJ positive for blaZ and mecA genes) and negative (reaction without DNA) controls were included. The PCR amplicons were separated on $2 \%$ agarose gel, stained $\left(\mathrm{SYBR}^{\circledR}\right.$ Safe DNA gel stain, Invitrogen, Thermo Fisher Scientific, Waltham, MA, USA), and visualized under UV light (Figure 1).

\section{RESULTS}

Among the 46 penicillin-resistant S. aureus strains, 44 (95.7\%) carried the blaZ gene and two (4.3\%) did not. Forty-five strains $(97.8 \%)$ were positive for $\beta$-lactamase based on the nitrocefin test. All strains were negative for the mecA gene.

Among the 44 blaZ-positive strains, 43 (97.7\%) were also positive for $\beta$-lactamase production and only one $(2.3 \%)$

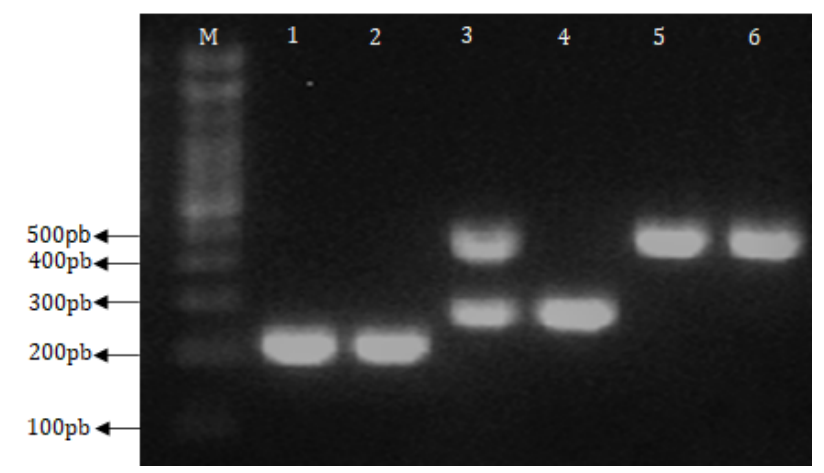

Source: Author's collection.

Figure 1. Agarose gel electrophoresis for visualization of the 165 (228 bp), blaZ (517 bp) and mecA (310 bp) amplicons. M: molecular weight marker (100 bp); lanes 1-2: 16S amplicon; lane 3: positive control; lane 4: mecA amplicon; lanes 5-6: positive isolates for blaZ. was not. The two strains that did not carry the blaZ gene were positive for $\beta$-lactamase production. The Table 1 shows these results.

\section{DISCUSSION}

Staphylococcus aureus is considered one of the most important and frequent etiologic agents of contagious bovine mastitis. The importance of this agent is due to its high frequency in herds throughout the world and because a large number of strains exhibit determinants of antimicrobial resistance, making antibiotic-based treatment difficult.

The results of the present survey corroborate these statements, as $95.7 \%$ of the $S$. aureus strains evaluated carried the blaZ gene. Other researchers have reported similar results. Martini et al. (2017), Aslantas; Demir (2016), Yang et al. (2015) and Krewer et al. (2014) evaluating S. aureus isolated from bovine mastitis, found high frequencies $(97,100$, 94.6 and $93 \%$, respectively) of the blaZ gene. Frequencies of positivity for blaZ below $50 \%$ have also been reported (ELSAYED et al., 2019; HAUBERT et al., 2017; SOUZA et al., 2019).

According to Nobrega et al. (2018), Haubert et al. (2017) and Srednik et al. (2015), the genus Staphylococcus maintains resistance determinants in mobile genetic elements, such as transposons and conjugative plasmids, contributing to the transferability of antimicrobial resistance genes among different species or genera, representing a potential risk to human and animal health.

It is noteworthy that $97.7 \%$ of the penicillin-resistant strains of $S$. aureus carrying the blaZ gene produced $\beta$-lactamase. Evaluating $S$. aureus strains isolated from subclinical bovine mastitis, Martini et al. (2017) detected the production of $\beta$-lactamase in $86.7 \%$ and Robles et al. (2014) in $78 \%$ of the $S$. aureus strains investigated. The results of the present investigation and previous studies suggest that the main $\beta$-lactam resistance mechanism in $S$. aureus isolated from bovine intramammary infection is enzymatic inactivation and that the enzyme may be actively produced in the mammary gland.

These results also suggest that $\beta$-lactam antimicrobials are extensively used in the herds analyzed, which favors the selection of resistant strains. Although there is a consensus regarding

Table 1. Frequency of blaZ and $\beta$-lactamase production in penicillin-resistant Staphylococcus aureus isolated from subclinical bovine mastitis in Garanhuns, PE, Brazil.

\begin{tabular}{l|c|c|c}
\multirow{2}{*}{ Genotype } & \multirow{2}{*}{$\mathrm{N}(\%)$} & \multicolumn{2}{|c}{$\beta$-lactamase } \\
\cline { 3 - 4 } & & $\begin{array}{c}\text { Positive } \\
\mathrm{N}(\%)\end{array}$ & $\begin{array}{c}\text { Negative } \\
\mathrm{N}(\%)\end{array}$ \\
\hline blaZ & & $43(97.7)$ & $1(2.3)$ \\
\hline blaZ & $44(95.7)$ & $2(100)$ & - \\
\hline
\end{tabular}

blaZ': strains harboring the gene; blaZ: strains not harboring the gene 
the need for the rational use of antibiotics, including for the treatment of mastitis, in practice, these drugs are employed abusively, particularly $\beta$-lactams (MESQUITA et al., 2019; SILVA et al., 2012; YANG et al., 2015).

$S$. aureus mastitis is the most challenging infectious disease in the veterinary practice of farm animals. The characteristic progression of the disease requires rapid decision-making regarding the establishment of the therapeutic and management protocol, the main objective of which is to eliminate sources of infection and decrease somatic cell counts in bulk milk. However, the indiscriminate use of antibiotics significantly compromises this goal.

The presence of penicillin-resistant and $\beta$-lactamaseproducing strains of $S$. aureus in dairy cattle, as demonstrated in this study, compromises the success of $\beta$-lactam therapy. Moreover, penicillin-resistant strains are more likely to respond poorly to non- $\beta$-lactam antibiotics than penicillin-susceptible strains. In addition, the pathogenicity islands where the penicillin resistance genes are located also have virulence factors and the co-expression of these genes contribute to bacterial survival in the presence of an antimicrobial agent (Barkema; Schukken; Zadoks, 2006).

This scenario is very worrisome. In practice, it reduces the chances of a bacteriological cure of staphylococcal mastitis, which, in turn, contributes to the dissemination and persistence of the pathogen in the herd.

In the present study the two penicillin-resistant $S$. aureus strains that did not harbor the blaZ gene were positive for $\beta$-lactamase production, whereas one strain harboring the blaZ gene was negative for $\beta$-lactamase production. The first case may be the result of changes in the nucleotide sequence in the primer alignment region, as described for other genes (HAUBERT et al., 2017; SZCZUKA et al., 2016). The second case may be due to an absence of blaZ gene expression, as argued by Srednik et al. (2015), but also due to low sensitivity of the nitrocefin disc method. Although nitrocefin method, as used in this study, detected the production of the $\beta$-lactamase in $97.7 \%$ of the blaZ positive $S$. aureus isolates, study conducted by Ferreira et al. (2017) showed a low sensitivity of this test. These authors comparing the sensitivity and specificity of the nitrocefin, disc diffusion, MIC, and zone edge tests for the detection of $\beta$-lactamase in Staphylococcus spp., found sensitivity as low as $28.9 \%$ for the nitrocefin test, although specificity was $100 \%$.

The findings highlighted above underscore the need to use a combination of results from two or more tests to detect $\beta$-lactam-resistant strains and confirm a penicillin-sensitive profile (HAUBERT et al., 2017; KAASE et al., 2008). One test should be a molecular method, which is more accurate for detecting the potential for a strain to produce $\beta$-lactamase (RUSSI et al., 2015). Although a molecular test should be considered, it is not always feasible in the routine of the veterinary laboratories due to the cost of required reagents and equipment. In these cases, and according to the results demonstrated in the present study, the disc diffusion test as well as the nitrocefin disc method can be used to investigate the potential for a strain of $S$. aureus to produce $\beta$-lactamase, since the great majority of the strains demonstrating resistance to penicillin were $\beta$-lactamase producers and carried the blaZ gene.

The mec $\mathrm{A}$ gene was not detected in any of the strains investigated in this study. Haubert et al. (2017) and Krewer et al. (2014) also did not detect the mecA gene in S. aureus isolated from bovine mastitis. However, Souza et al. (2019) and Liu et al. (2017) found frequencies of 30 and $31.25 \%$ for the mecA gene in strains of $S$. aureus isolated from bovine mastitis and Elsayed et al. (2019) reported a frequency of $75 \%$ in strains isolated from the milk of healthy cows and buffaloes as well as those with mastitis.

The low frequency or even absence of the mecA gene is expected in animal isolates. According to Virdis et al. (2010), the presence of the mecA gene and, consequently, methicillinresistant strains is low in bacteria of an animal origin. On the other hand, the low frequency or absence of mecA could be explained by its genetic instability, which hinders the alignment of primers and, consequently, amplification (HAUBERT et al., 2017; SZCZUKA et al., 2016). In this specific case, homologous genes to $m e c \mathrm{~A}$, such as $m e c \mathrm{~B}$ and $m e c \mathrm{C}$, should be investigated, especially when a high rate of cefoxitin resistance has been detected.

It is noteworthy that the absence of the mecA gene in the $S$ aureus strains evaluated in the present study, agrees with the profile of susceptibility to oxacillin reported by Silva et al. (2012) for the same isolates. According to these authors, 99 and $1 \%$ of the strains were classified in the sensitive and intermediate categories, respectively. Currently, the cefoxitin disk test is recommended to detect methicillin-resistant Staphylococcus spp. as it has higher specificity than and equal sensitivity to the oxacillin disk test (CLSI, 2018). However, the results of the present study suggest that oxacillin disk test has high specificity and sensibility, since there was $100 \%$ of agreement between this test and PCR.

\section{CONCLUSION}

The results reveal that enzymatic $\beta$-lactam inactivation is the main antimicrobial resistance mechanism expressed by $S$. aureus in the herds evaluated. The results also indicate that milk produced in the evaluated region represent a risk to public health, since it may transmit antibiotic residues and bacteria carrying resistance genes.

\section{ACKNOWLEDGMENT}

This work was funded by the Brazilian National Research Council [scholarship grant 2017-2018/2018-2019] and the State of Pernambuco Science and Technology Assistance Foundation [grant numbers APQ-0398-5.04/2015]. 


\section{REFERENCES}

ABEBE, R. et al. Bovine mastitis: prevalence, risk factors and isolation of Staphylococcus aureus in dairy herds at Hawassa milk shed, South Ethiopia. BMC Veterinary Research, v. 12, n. 1, p. 270, 2016.

AGUAYO-REYES, A. et al. Bases moleculares de la resistencia a meticilina en Staphylococcus aureus / Molecular basis of methicillin-resistance in Staphylococcus aureus. Revista Chilena de Infectologia, v. 35, n. 1, p. 7-14, 2018

ARAÚJO, G. B. et al. Detecção de resíduo de antibiótico em leite in natura em laticínio sob inspeção federal. Scientia Plena, v. ll, ก. 4, 2015 .

ARÍZA-MIGUEL, J. et al. Methicillin-resistant Staphylococcus aureus harboring mecC in livestock in Spain. Journal of Clinical Microbiology, v. 52, n. 11, p. 4067-4069, 2014.

ASLANTAS, Ö.; DEMIR, C. Investigation of the antibiotic resistance and biofilm-forming ability of Staphylococcus aureus from subclinical bovine mastitis cases. Journal Dairy Science, v. 99, n. 11, p. $8607-$ $8613,2016$.

BARKEMA, H.W.; SCHUKKEN, Y. H.; ZADOKS, R. N. The role of cow, pathogen, and treatment regimen in the therapeutic success of bovine Staphylococcus aureus mastitis. Journal of Dairy Science, v. 89, n .6, p. 1877-1895, 2006.

BORELLI, B. M. et al. Enteroxigenic Staphylococcus spp. and other microbial contaminants during production of Canastra cheese, Brazil. Brazilian Journal of Microbiology, v. 37, n. 4, p. 545-550, 2006.

CLINICAL LABORATORY STANDARDS INSTITUTE. Performance standards for antimicrobial disk and dilution susceptibility tests for bacteria isolated from animals. 3th ed. Wayne: CLSI, 2008. $116 p$.

CLSI. Performance Standards for Antimicrobial Disk and Dilution Susceptibility Tests for Bacteria Isolated from Animals. 5th ed. CLSI standard VETOI. Wayne, PA: Clinical and Laboratory Standards Institute, 2018.

CUNHA, A. F. et al. Prevalência, etiologia e fatores de risco de mastite subclínica em rebanhos leiteiros de Viçosa-MG. Acta Veterinaria Brasilica, v. 9, n. 2, p. 160-166, 2015

ELSAYED, M. S. A. E. et al. Phenotypic and genotypic methods for identification of slime layer production, efflux pump activity, and antimicrobial resistance genes as potential causes of the antimicrobial resistance of some mastitis pathogens from farms in Menoufia, Egypt. Molecular Biology Reports, v. 46, n. 6, p. 6533-6546, 2019.

FELIPE, V. et al. Evaluation of the biofilm forming ability and its associated genes in Staphylococcus species isolates from bovine mastitis in Argentinean dairy farms. Microbial Pathogenesis, $v$. 104, п. 2017, p. 278-286, 2017.

FERREIRA, A. M. et al. Correlation of phenotypic tests with the presence of the blaZ gene for detection of beta-lactamase. Brazilian Journal of Microbiology, n. 48, p. 159-166, 2017.

FONTES, C. O. et al. Prevalence, Antimicrobial Resistance, and Virulence Characteristics of mecA-Encoding Coagulase-Negative Staphylococci Isolated from Soft Cheese in Brazil. Journal of Food Science, v. 78, p. M594-M599, 2013.
FREITAS, C. H. et al. Identification and antimicrobial suceptibility profile of bacteria causing bovine mastitis from dairy farms in Pelotas, Rio Grande do Sul. Brazilian Journal of Biology, v. 78, n. 4, p. 661-666, 2018.

GARCÍA-ÁLVAREZ, L. et al. Meticillin-resistant Staphylococcus aureus with a novel mecA homologue in human and bovine populations in the UK and Denmark: a descriptive study. The Lancet Infections Diseases, v. 11, п. 8, p. 595-603, 2011.

GIRARDINI, L. K. et al. Antimicrobial resistance profiles of Staphylococcus aureus clusters on small dairy farms in southern Brazil. Pesquisa Veterinária Brasileira, v. 36, n. 10, p. 951-956, 2016.

HARRISON, E. M. et al. A novel hybrid SCCmec-mecC region in Staphylococcus sciuri. Journal of Antimicrobial Chemotherapy, v. 69, п. 4, p. 911-918, 2014

HASSANZADEH, S. et al. TENT: A Rapid DNA Extraction Method of Staphylococcus aureus. Iranian Journal of Public Health, v. 45, ก. 8, p. 1093-1095, 2016.

HAUBERT, L. et al. Microbial Pathogenesis First report of the Staphylococcus aureus isolate from subclinical bovine mastitis in the South of Brazil harboring resistance gene dfrC and transposon family Tn 916-1545. Microbial Pathogenesis, v. 113, p. 242-247, 2017.

HOCEVEEN, H.; VANDERVOORT, M. Assessing the economic impact of an endemic disease: the case of mastitis. Revue Scientifique et Technique, v. 36, n. 1, p. 217-226, 2017

KAASE, M. et al. Comparison of phenotypic methods for penicillinase detection in Staphylococcus aureus. Clinical Microbiology and Infection, v. 14, n. 6, p. 614-616, 2008.

KANE, T. L.; CAROTHERS, K. E.; LEE, S. W. Virulence Factor Targeting of the Bacterial Pathogen Staphylococcus aureus for Vaccine and Therapeutics. Current Drug Targets, v. 19, n. 2, p. $111-127,2018$.

KLIMIENE, I. et al. Phenotypical and genotypical antimicrobial resistance of coagulase-negative staphylococci isolated from cow mastitis. Polish Journal of Veterinary Sciences, v. 19, p. 639-646, 2016

KREWER, C. C. et al. Resistance to antimicrobials and biofilm formation in Staphylococcus spp. isolated from bovine mastitis in the Northeast of Brazil. Tropical Animal Health and Production, v. 47, п. 3, p. 511-518, 2014.

LAVOR, U. L. et al. Bacterial identification, somatic cell count, antimicrobial profile and toxigenic Staphylococcus strains search from mastitic cow milk samples on small farms properties. Pesquisa Veterinária Brasileira, v. 39, n. 9, p. 715-722, 2019.

LIU, H. et al. Prevalence, antimicrobial susceptibility, and molecular characterization of Staphylococcus aureus isolated from dairy herds in northern China. Journal of Dairy Science, v. 100, n. 11 , p. 8796-8803, 2017.

LONCARIC, I. et al. Characterization of mecC gene-carrying coagulasenegative Staphylococcus spp. isolated from various animals. Veterinary Microbiology, v. 230, p. 138-144, 2019. 
MACFADYEN, A. C. et al. A mecC allotype, mecC3, in the CoNS Staphylococcus caeli, encoded within a variant SCCmecC. Journal of Antimicrobial Chemotherapy, v. 74, n. 3, p. 547-552, 2019.

MARTINI, C. L. et al. Characterisation of penicillin and tetracycline resistance in Staphylococcus aureus isolated from bovine milk samples in Minas Gerais, Brazil. Journal of Dairy Research, v. 84, п. 2, p. 202-205, 2017.

MESQUITA, A. A. et al. Staphylococcus aureus and Streptococcus agalactiae: prevalence, resistance to antimicrobials, and their relationship with the milk quality of dairy cattle herds in Minas Gerais state, Brazil. Pesquisa Veterinária Brasileira, v. 39, п. 5, p. 308-316, 2019.

MIRANDA, M. M. M.; ARANGO, F. O. D. Evaluación de la calidad de la leche cruda recibida en industrias lácteas de Manizales. Producción + Limpia, v. 11, n. 1, p. 75-84, 2016.

MONDAY, S. R.; BOHACH, G. A. Use of Multiplex PCR to detect classical and newly described pyrogenic toxin genes in Staphylococcal isolates. Journal of Clinical Microbiology, v. 37, p. 3411-3414, 1999.

NOBRECA, D. B. et al. Prevalence and Genetic Basis of Antimicrobial Resistance in Non- aureus Staphylococci Isolated from Canadian Dairy Herds. Frontiers of Microbiology, v. 9, p. 256, 2018.

OLSEN, J. E.; CHRISTESEN, H.; AARESTRUP, F. M. Diversity and evolution of blaZ from Staphylococcus aureus and coagulasenegative staphylococci. Journal of Antimicrobial Chemother, v. 57, n. 3, p. 450-460, 2006.

OTTO, M. Staphylococcus aureus toxins. Current Opinion in Microbiology, v. 17, p. 32-37, 2014.

ROBLES, B. F. et al. Detecção de beta-lactamase em Staphylococcus aureus e Staphylococcus coagulase negativa isolados de mastite bovina. Pesquisa Veterinária Brasileira, v. 34, n. 4, p. 325-328, 2014.
RUSSI, N. et al. Comparison of phenotypic tests for detecting penicillin $G$ resistance with presence of blaZ gene in Staphylococcus aureus isolated from bovine intramammary infections. Journal of Dairy Research, v. 82, п. 3, p. 317-321, 2015.

SAWANT, A. A.; GILLESPIE, B. E.; OLIVER, S. P. Antimicrobial susceptibility of coagulase-negative Staphylococcus species isolated from bovine milk. Veterinary Microbiology, v. 134, n. l-2, p. 73-81, 2009.

SILVA, E. R. et al. Perfil de sensibilidade antimicrobiana in vitro de Staphylococcus aureus isolado de mastite subclínica bovina. Revista Brasileira de Saúde e Produção Animal, v. 13, n. 3, p. 701-711, 2012

SOUZA, G. Á. A. D. et al. Characterization and molecular epidemiology of Staphylococcus aureus strains resistant to beta-lactams isolated from the milk of cows diagnosed with subclinical mastitis. Veterinary World, v. 12, n. 12, p. 1931-1939, 2019.

SREDNIK, M. E. et al. Molecular identification of coagulase-negative staphylococci isolated from bovine mastitis and detection of $\beta$-lactam resistance. The Journal of Infection in Developing Countries, $v$. 9, p. 1022-1027, 2015.

SZCZUKA, E. et al. Diversity of staphylococcal cassette chromosome mec elements in nosocomial multiresistant Staphylococcus haemolyticus isolates. Journal of Applied Genetics, v. 57, p. 543-547, 2016.

VIRDIS, S. et al. Antibiotic Resistance in Staphylococcus aureus and Coagulase Negative Staphylococci Isolated from Goats with Subclinical Mastitis. Veterinary Medicine International, 2010.

YANG, F. et al. Prevalence of blaZ gene and other virulence genes in penicillin-resistant Staphylococcus aureus isolated from bovine mastitis cases in Gansu, China. Turkish Journal of Veterinary \& Animal Sciences, v. 39 ก. 5, p. 634-636, 2015. 